\title{
THE FIRST RECORD IN CENTRAL EUROPE OF THE ALIEN INVASIVE ROTAN, PERCCOTTUS GLENII, IN THE DIET OF THE EUROPEAN PERCH PERCA FLUVIATILIS
}

\section{Thomas Oliver Méró}

\begin{abstract}
Nature Protection and Study Society - NATURA, Milana Rakića 20, SRB-25000 Sombor, Serbia Department of Tisza Research, Danube Research Institute, Centre for Ecological Research, Hungarian Academy of Sciences, Bem tér 18/c, HU-4026 Debrecen, Hungary (e-mail: thomas.oliver.mero@gmail.com)
\end{abstract}

Mérö, Th. O.: The first record in Central Europe of the alien invasive rotan, Perccottus glenii, in the diet of the European perch Perca fluviatilis. Nat. Croat., Vol. 25, No. 1, 155-157, 2016, Zagreb.

In the spring of 2011, an individual of the rotan, Perccottus glenii Dybowski 1877, was found in the stomach of a European perch, Perca fluviatilis L., captured in a drainage-irrigation channel in eastern Hungary. This is the first recording of the rotan found in the diet of the European Perch in Central Europe.

Key words: invasive species, stomach content, rotan, Perccottus glenii, Perca fluviatilis

Mérő, Th. O.: Prvi srednjoeuropski nalaz alohtone invazivne vrste amurskog spavača Perccottus glenii u ishrani grgeča Perca fluviatilis. Nat. Croat., Vol. 25, No. 1, 155-157, 2016, Zagreb.

U proljeće 2011. jedan je primjerak amurskog spavača Perccottus glenii Dybowski 1877 nađen u želucu grgeča ulovljenog u drenažno-irigacijskom kanalu u istočnoj Mađarskoj. To je prvi nalaz amurskog spavača u ishrani grgeča u srednjoj Europi.

Ključne riječi: invazivne vrste, sadržaj želuca, amurski spavač, Perccottus glenii, Perca fluviatilis

The diet and the feeding habits of the European perch, Perca fluviatilis L., has been extensively studied in Europe (e.g. Dörner et al., 2003; Lorenzoni et al., 2007), Australia and New Zealand (e.g. SABETIAN et al., 2015). Although predominantly invertebrates are found in the diet of this species, vertebrates such as fish or small amphibians are also components (LoREnzoni et al., 2007; Akin et al., 2012). A number of studies have reported on the expansion of the alien rotan or Amur sleeper, Perccottus glenii Dybowski 1877, in Eastern and Central Europe (e.g. Koščo et al., 2003; Reshetnikov, 2004; Hegediš et al., 2007; Reshetnikov, 2013; Reshetnikov \& Schliewen, 2013). This species was first recorded in Central Europe in the basin of the River Tisza (Koščo et al., 2003), later in the basin of the River Danube (Simonović et al., 2006; ĆAlEta et al., 2010; CovaCiu-Marcov et al., 2011) and subsequently in the drainage area of the Upper Danube (Reshetnikov \& Schliewen, 2013). Reshetnikov (2013) mentioned that some authors considered that the spread of the rotan in European freshwaters could well lead to the decline or even the local extinction of native fish species such as the vulnerable mudminnow, Umbra krameri, the lake minnow, Phoxinus percnurus, or the bitterling, Rhodeus sericeus. However, studies in the region of Lake Baikal lead to the conclusion that native fish predators may be able to control the rotan (Litvinov \& O'Gorman 1996). The aim of the present paper 
is to report that this alien invasive species, the rotan, has now been recorded as a new prey-fish species in the diet of the European perch.

The study was conducted in a drainage-irrigation canal near the settlement of Egyek in eastern Hungary $\left(\mathrm{N} 47.59^{\circ}, \mathrm{E} 20.96^{\circ}\right)$. The depth of the canal varies between 0.5 and $1 \mathrm{~m}$, with an average width of approximately $3 \mathrm{~m}$. The banks and often the entire surface of the canal are overgrown with reed Phragmites australis. The water is rich in submerged vegetation. European perch were captured by angling (ArLinghaus, et al. 2008; Méró, 2014, 2015) between 10 and 12 a.m. on 11 April, 2011. I used housefly, Musca domestica, maggots as bait. Immediately after the capture, the fish were killed in order to slow down the digestion, and the contents of their stomachs were investigated within one hour. The lengths of both the European perch and the prey fish were measured with a ruler.

Two European perch were captured, with lengths of 15.0 and $19.5 \mathrm{~cm}$. The stomach of the smaller individual was empty, whereas one individual rotan was found in the larger European perch. The rotan was $4.5 \mathrm{~cm}$ long and was slightly digested. As far as I am aware this is the first recording in Central Europe of the rotan in the diet of the European perch.

Although Litvinov \& O'Gorman (1996) described the presence of the rotan in the stomachs of European perch and pike, Esox lucius, in the Lake Baikal region, the present report is the first recording of an individual in the stomach of a European perch in Europe. Moreover, this finding of the rotan as prey is particularly interesting because, in contrast with the Lake Baikal region (Litvinov \& O'Gorman, 1996; Reshetnikov, 2013), the abundance of this species in Central Europe is still low (Simonović et al., 2006; ĆALETA et al., 2010; Covaciu-MARcov et al., 2011). The small canal where the two European perches were captured is directly connected with the backwater where the stomach content of 112 pike Esox lucius were examined but no rotan was recorded (MÉró, 2015). This suggests that the number of the rotan may be lower than assumed by FreYHOF (2003). However, for a reliable conclusion, systematic monitoring on a European level of this species is needed.

\section{ACKNOWLEDGEMENTS}

I thank Renáta Bocz for the support during the fieldwork.

Received June 15, 2015

\section{REFERENCES}

Akin, Ş., Şahin, C., Verep, B., Turan, D., Gözler, A. M., Bozkurt, A., Çelik, K., Çetin, E., Aracl, A. \& SARG1N, I., 2011: Feeding habits of introduced European perch (Perca fluviatilis) in an impounded large river system in Turkey. African Journal of Agricultural Research 6, 4293-4307.

Arlinghaus, R., Klefoth, T., Gingerich, A. J., Donaldson, M. R., Hanson, K. C. \& Cooke, S. J., 2008: Behavioral and survival of pike, Esox lucius, with a retained lure in the lower jaw. Fisheries Management and Ecology 15, 459-466.

Ćaleta, M., Jelić, D., Buj, I., Zanella, D., Marčić, Z., Mustafić, P. \& Mrakovčić, M., 2011: First record of the alien invasive species rotan (Perccottus glenii Dybowski, 1877) in Croatia. Journal of Applied Ichthyology 27, 146-147.

Covaciu-Marcov, S-D., Telcean, I. C. \& Ferenti, S., 2011: Range extension of Perccottus glenii Dybowski, 1877 in Western Romania, a new distribution route in the Danube River Basin? Journal of Applied Ichthyology 27, 144-145. 
Dörner, H., Berg, S., Jacobsen, L., Hülsmann, S., Brojerg, M. \& Wagner, A., 2003: The feeding behaviour of large perch Perca fluviatilis (L.) in relation to food availability: a comparative study. Hydrobiologia 506-509, 427-434.

FREYHOF, J. 2003: Immigration and potential impacts of invasive freshwater fishes in Germany. Berlin IGB $17,51-58$.

Hegediš, A., Lenhardt, M., MićKović, B., Cvijanović, G., Jarić, I. \& Gačić, Z., 2007: Amur sleeper (Perccottus glenii Dubowski, 1877) spreading in the Danube River Basin. Journal of Applied Ichthyology 23, 705-706.

Koščo, J., Lusk, S., HalačKa, K. \& Lusková, V., 2003: The expansion and occurrence of the Amur sleeper (Perccottus glenii) in eastern Slovakia. Folia Zoologica 52, 329-336.

Litvinov, A. G. \& O'Gorman, R., 1996: Biology of Amur sleeper (Perccottus glehni) in the delta of the Selenga river, Buryatia, Russia. Journal of Great Lakes Research 22, 370-378.

Lorenzoni, M., Carosi, A., Pedicillo, G. \& Trusso, A., 2007: A comparative study on the feeding competition of the European perch Perca fluviatilis L. and the ruffe Gymnocephalus cernuus L. in Lake Piediluco (Umbria, Italy). Bulletin Français de la Pêche et de la Pisciculture 387, 35-57.

Méró, T. O., 2014: Diet in pike (Esox lucius) in northwestern Vojvodina (Serbia). Natura Croatica 23, 27-34.

Méró, T. O., 2015: The first recording of the threatened species, the European weather loach, Misgurnus fossilis (Berg, 1949), in the diet of the pike. Turkish Journal of Zoology 39, 967-970.

Reshetnikov, A. N., 2004: The fish Perccottus glenii: history of introduction to western regions of Eurasia. Hydrobiologia 522, 349-350.

Reshetnikov, A. N., 2013: Spatio-temporal dynamics of the expansion of rotan Perccottus glenii from West-Ukrainian centre of distribution and consequences for European freshwater ecosystems. Aquatic Invasions 8, 193-206.

Reshetnikov, A. N. \& Schliewen, U. K., 2013: First record of the invasive alien fish rotan Perccottus glenii Dybowski, 1877 (Odontobutidae) in the Upper Danube drainage (Bavaria, Germany). Journal of Applied Ichthyology 29, 1367-1369.

Sabetian, A., Trip, E. D. L., Wheeler, P., Sands, L., Wakefield, S., Visconti, V. \& Banda, F., 2015. Biological plasticity of non-native European perch (Perca fluviatilis) populations and the implications for management in northern New Zealand. New Zealand Journal of Marine Freshwater Research 49, 119-131.

Simonović, P., Marić, S. \& Nikolić, V., 2006: Records of Amur sleeper Perccottus glenii (Odontobutidae) in Serbia and its recent status. Archives of Biological Sciences 58, 7-8.

\title{
SAŽETAK
}

\section{Prvi srednjoeuropski nalaz alohtone invazivne vrste amurskog spavača Perccottus glenii $\mathbf{u}$ ishrani grgeča Perca fluviatilis}

\author{
Th. O. Mérő
}

U proljeće 2011. godine u želucu grgeča, Perca fluviatilis L., uhvaćenog u drenažno-irigacijskom kanalu u istočnoj Mađarskoj nađen je jedan primjerak amurskog spavača, Perccottus glenii Dybowski 1877. Prema dosadašnjim saznanjima, ovo je prvi nalaz amurskog spavača u ishrani grgeča u središnjoj Europi. 